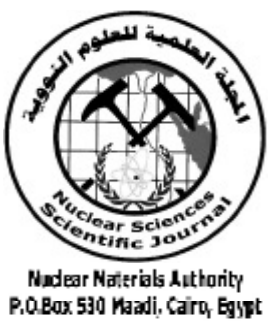

ISSN 2314-5609

Nuclear Sciences Scientific Journal

$5,161-177$

2016

http://www.ssnma.com

\title{
A STUDY OF NATURAL RADIOACTIVE HAZARDS IN METOUBAS AREA, NILE DELTA COAST, EGYPT: ASSESSMENT AND MITIGATION
}

\author{
HAMDY I. E. HASSANEIN; KANDIL M. KANDIL and GEHAD M. R. MANSOUR \\ Nuclear Materials Authority (NMA), P.O. Box: 530 El Maadi, Cairo, Egypt
}

\begin{abstract}
The Egyptian mineral sand deposits are beach placer deposits which involve enormous quantities of potentially economic heavy minerals. These minerals occur in variable proportions, mixed with the beach of the Mediterranean Sea of Egypt along a stretch of about $400 \mathrm{~km}$, extending from Rafah eastward to Abu Qir westwards. In addition, these contain different concentrations of radioactive minerals that are considered as raw materials for nuclear energy use. In other hand, the radioactive hazard is mainly attributed to the occurrences of radioactive minerals such as monazite and zircon that host uranium and thorium minerals in the beach black sand deposits.

The present study introduced a regime of methods to allow the correct assessment of the radioactive hazards arising from the radioactive mineral content in the beach sand of Metoubas area at the northern cost of Nile Delta of Egypt. Also the studies give recommendations to be applied on the site or area before, during and after the implementation of any constructions in order to satisfy the radioactive safety conditions suggested by the International Atomic Energy Agency (IAEA). Therefore, this study was conducted as a case study on the northern cost of Egypt.

The ground spectrometry has been used to measure the radioactivity. In addition, samples of beach sediments from Metoubas area were collected in order to measure radioactive concentrations of ${ }^{226} \mathrm{Ra},{ }^{232} \mathrm{Th},{ }^{238} \mathrm{U}$ and ${ }^{40} \mathrm{~K}$ by gamma spectrometry carried out in NMA laboratories. The exposure dose rates assessed are determined; and estimations of the effective dose rate equivalents and health risk assessment on humans have been determined. Results showed low levels of radioactivity in Metoubas beach sediments of the eastern zone where as the western and central zones showed moderate radioactivity. The principal radiation risks are gamma radiation, essentially from radium; windblown radioactive dust dispersal and radon gas and its radioactive progeny, which are known to cause lung cancer.

It also reveals that the dose rates sharply decrease towards the southeastern zone. In addition, the exploration results obviously demonstrate that the mineral concentration in the beach sediments of the site is increasing due west of limited mineralization which occurs in this part. This part of resource in site area can be scarped to be utilized later in any future exploration plans conducted in the Abu KhashabaMetoubas mineral zone.
\end{abstract}

Furthermore, the obtained data set could be used as background levels for future research applications and development of environmental regulatory frameworks along the northern coast. 


\section{INTRODUCTION}

Radioactive materials which occur naturally and where human activities increase the exposure of people to ionizing radiation are known by the acronym "NORM". NORM is an acronym for Naturally Occurring Radioactive Material, which potentially includes all radioactive elements found in the environment (IAEA, 2010).

NORM results from activities such as burning coal, making and using fertilizers and black sand minerals production. The Egyptian coastal zone is a crucial part of the economy and represents a promising target for the development as it supplies a living for a large number of people along the coast. The black sand deposits along the northern coast contain zircon, magnetite, garnet, ilmenite, titanite and rutile. These minerals are very useful in many industrial applications such as pigment, ceramics, welding arcs, etc.

A fundamental aspect of this study is that it provides guidance to determine the best remediation procedures and are a cost effective method of the radioactive and minerals site assessment for environmental development of the northern coast of Egypt along a stretch of about $400 \mathrm{~km}$, extending from Rafah eastward to Abu Qir westwards where black sand minerals accumulated to form huge ore deposits (EBASCO, 1964). Abdel Razek et al. (2009) estimated the radiation hazard at Baltim area.

This study introduces a regime of methods to allow the correct assessment of the radioactive hazards arising from the radioactive mineral content in the beach sand of Metoubas area which require exploitation. Also the studies gives recommendations to be applied to the site or area before, during and after implementation of any constructions in order to satisfy the radioactive safety conditions suggested by the International Atomic Energy Agency (IAEA, 2010). Therefore, this study was conducted at Metoubas as a case study area on the northern beach. This study includes ground detailed radio-spectrometric survey, field sample collection, mineralogical and radio-elements laboratory analysis. In addition, the study has included data acquisition and analyses of the collected data as well as the assessment of the current radioactive hazard arising from the radioactive mineral contents in the beach sand of the site.

\section{Location of the Study Area}

The investigated area lies on the coast of the Mediterranean Sea to the east of Rosetta branch of the Nile River (Fig. 1). The area is almost a rectangular beach strip of about 2 $\mathrm{km}$ long and $1 \mathrm{~km}$ width between Lat. $31^{\circ} 26^{\prime}$ $29.1^{\prime \prime}$ and $31^{\circ} 27^{\prime} 3.0^{\prime \prime} \mathrm{N}$ and long. 30 $28^{\prime} 1.5^{\prime \prime}$ and $30^{\circ} 29^{\prime} 16.2^{\prime \prime} \mathrm{E}$. This site was previously included in the bigger beach strip extending along the entire Mediterranean coast in which the Nuclear Materials Authority was licensed for exploration and exploitation of the mineral sand deposits.

During the period 1999-2002, the site was primarily covered by airborne gamma spectrometric survey conducted by NMA as a part of a comprehensive exploration study covering the entire Mediterranean Coast. Therefore, the aero-radiometric map relevant to this site was utilized in the present study (Fig. 2).

\section{Airborne Radiometric Survey}

Metoubas lies within a bigger area east of Abu Khashaba where airborne radiometric

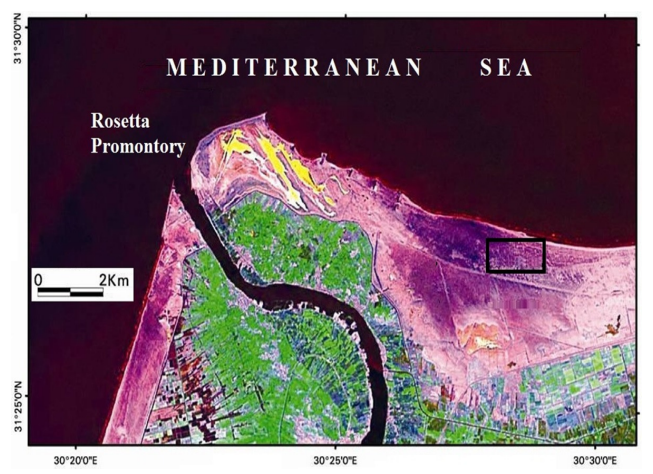

Fig. 1: False colour composite image showing the location of studied area outside the cultivated and urban land 


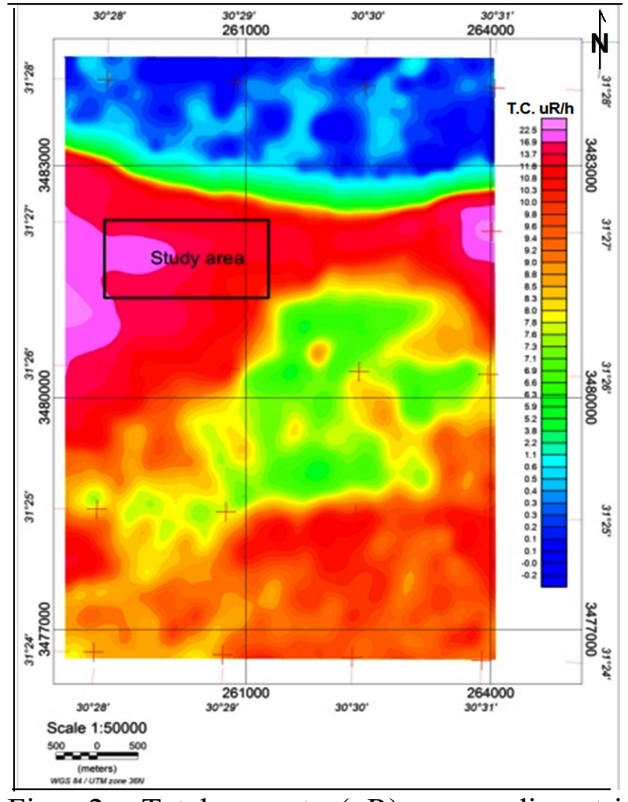

Fig. 2: Total count $(\mu \mathrm{R})$ aeroradiometric coloured contour map of the area under study and surroundings, modified (After El Sirafy, et al., 2002)

surveying of the area provided information summarizing its radiometric characterization in Table (1). Figure (2) illustrates coloured contour map of total count measurements expressed by ( $\mathrm{TC}$ in $\mu \mathrm{R} / \mathrm{h}$ ) of gamma radiation.

The study area is outlined on the aeroradiometric and aeroradio-spectrometric maps. The study area corresponds to high to very high TC, eU and eTh levels according to (IAEA, 1991). In addition it corresponds to low to moderate $\mathrm{K}^{40}$ level (IAEA, 1991).

\section{Geologic Investigations}

The geology of these beach deposits along the Mediterranean coast is directly related to the development of the Nile Delta and the past configuration of the Nile branch (Hammoud, 1966).

The geomorphological features of the northern coast of Nile Delta of Egypt were supplemented by earlier geological data
Table 1: The radiometric characterization of west Abu Khashaba black sands, inferred from the airborne gamma-ray survey (El Sirafy et al., 2002)

\begin{tabular}{lr}
\hline Radiometric element & Average \\
\hline $\mathrm{TC} \mu \mathrm{R} / \mathrm{h}$ & 19.7 \\
$\mathrm{~K} \%$ & 1.27 \\
$\mathrm{eU}$ ppm & 11.4 \\
eTh ppm & 22.43 \\
\hline
\end{tabular}

given in different sources (El Fishawi and El- Askary, 1981; El Fishawi, 1985 and Frihy, 1988). The area under study lies to the east of the Rosetta Nile branch. In this district; the black sands are dispersed along the strip parallel to the Mediterranean Sea beach to a depth of more than $10 \mathrm{~m}$, accordingly, the nuclear environment pollution in this district is due to the concentration of these radioactive minerals at or near ground surface. The beach and backshore flats are composed of loose fine to coarse quartz sand, mixed with small amounts of heavy minerals and shell fragments having a width ranges between 1500 to $2000 \mathrm{~m}$ from the shoreline. The shape and extension of the beach are changed as a result of the human activities and the extensive erosion mechanism.

\section{Benefits of the Study}

-Reduces uncertainty in the estimates of contaminated land and facilities.

-Ensures minimal safety and health impact to cleanup workers and the environment.

-Produces reliable estimates of radioactive risk volumes generated during human activities.

- Greatly enhances public credibility and builds stakeholder trust in environmental cleanup activities.

\section{METHODS APPLIED}

Techniques and methodology of this study include the following (Fig. 3). 


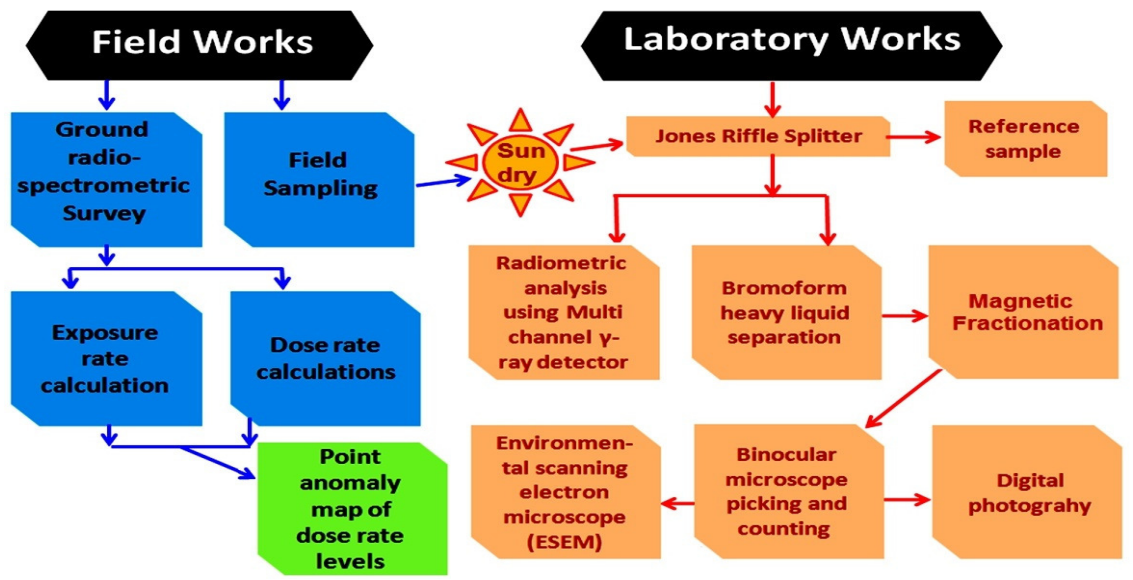

Fig. 3: Flow sheet showing the methods applied to the present study

\section{Field Works}

\section{Ground radio-spectrometric survey}

Detailed spectral gamma ray measurements have been conducted along 40 equally spaced profiles, directed N-S, with a distance of about $2 \mathrm{~km}$ along the beach and about 1 $\mathrm{km}$ spacing. Spectral gamma-ray measurements have been conducted using a portable gamma ray spectrometer model GS-512 Geofyzika Brno, Czeck Republic. The total number of survey lines was 21 with $2 \mathrm{~km}$ long. The spacing between the survey lines was set at $50 \mathrm{~m}$ and between stations along traverse lines was set at $50 \mathrm{~m}$ (861 total numbers of stations).

\section{Field sampling}

Sixty boreholes of beach sediments of 50 $\mathrm{cm}$ depth and diameter $10 \mathrm{~cm}$ were collected by auger with an average weight of $3 \mathrm{~kg}$ for each sample. These boreholes were distributed in three N-S (perpendicular to shore line direction) profiles with $1 \mathrm{~km}$ long each and 50 $\mathrm{m}$ spacing between boreholes in each profile (Fig. 4).

\section{Laboratory Works}

The sixty samples were treated (analyzed) in laboratory of Nuclear Materials Authority in Qattamyia, Cairo. These samples were sun

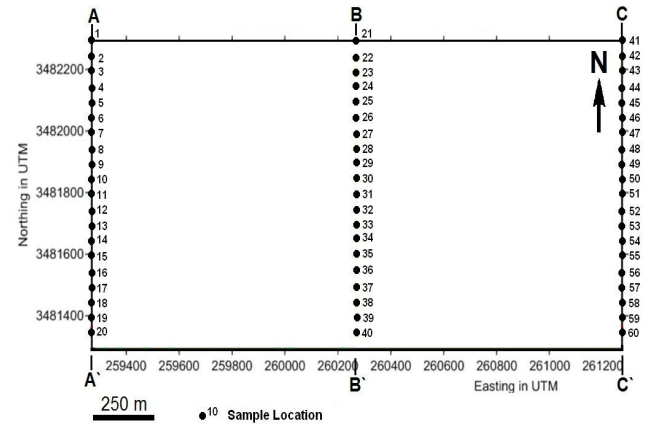

Fig. 4: Diagram showing the three profiles (A$A^{\prime}, B^{\prime}-B^{\prime}$ and $C-C^{\prime}$ ) were used to collect 60 field borehole samples

dried and quartered by Jones Riffle splitter into three representative portions. One portion was stored as reference sample, while the second portion was used for heavy liquid and magnetic separation, microscopic hand picking counting and ESEM analyses. The third portion was used for radiometric analysis after one month.

\section{Separation of the heavy minerals using heavy liquids}

Separation by heavy liquid (bromoform sp. gr. $=2.89 \mathrm{gm} / \mathrm{cm}^{3}$ ) into two fractions (light and heavy) then both fractions were dried, weighed and tabulated. The light fractions 
were discarded while the heavy fractions were subjected to magnetic fractionation.

\section{Magnetic fractionation}

The obtained heavy bromoform fractions were subjected to magnetic fractionation using a Carpco MLT 13/111/5 lift type magnetic separator. The used current values were; magnetic $0.07 \mathrm{~A}, 0.8 \mathrm{~A}, 0.1 \mathrm{~A}, 2 \mathrm{~A}$ and nonmagnetic $2 \mathrm{~A}$ fractions.

\section{Binocular microscopic picking and counting}

The heavy liquid fractions were subjected to identification and counting under the binocular microscope. Magnetic fractionation was done to facilitate mineral identification. Each of the obtained magnetic fractions was quartered to obtain small representative samples.

\section{Environmental scanning electron microscope (ESEM) analysis}

Semi-quantitative analysis of the different heavy minerals was undertaken in the ESEM analysis using Philips XL 30 aperture attached with EDX unit. ESEM technique can be used to examine mineral composition, inclusions within mineral grains and the surface features on the mineral grains.

\section{Radiometric analysis}

The radiometric levels of the collected samples were determined through ground radio-spectrometric survey measurements where, eU (ppm), eTh (ppm), and K (\%) contents are determined by using multichannel analyzer of $\gamma$-ray detector.

\section{RESULTS AND DISCUSSIONS}

\section{Heavy Mineral Analysis}

The total heavy mineral content of the studied beach samples varies between $11.13 \%$ and $28.89 \%$ (Table 2) with an average of $19.23 \%$. Mineralogical analysis has shown that the mineral components includes small percentage of the economic minerals represented by magnetite, ilmenite, leucoxene, garnet, zircon (Fig. 5), rutile, titanite was also detected in minor amount and abundance of non economic minerals represented by colored silicate minerals such as apatite, amphibole and pyroxene (gangue minerals) and trace of radioactive minerals (monazite, Fig. 6).

Table 2: The analysis of the different fractions separated by bromoform of 60 representative samples, Metoubas area, Northern Nile Delta, Egypt

\begin{tabular}{|c|c|c|c|c|c|c|c|}
\hline S. No. & Slime \% & $\begin{array}{c}\text { Light bromoform } \\
\text { fraction } \%\end{array}$ & $\begin{array}{c}\text { Heavy bromoform } \\
\text { fraction } \%\end{array}$ & S. No. & Slime \% & $\begin{array}{c}\text { Light bromoform } \\
\text { fraction } \%\end{array}$ & $\begin{array}{c}\text { Heavy bromoform } \\
\text { fraction \% }\end{array}$ \\
\hline$\overline{1}$ & 2.92 & 85.41 & 11.67 & 31 & 1.93 & 79.23 & 18.84 \\
\hline 2 & 1.54 & 78.75 & 19.71 & 32 & 2.45 & 79.20 & 18.35 \\
\hline 3 & 2.40 & 77.01 & 20.59 & 33 & 2.64 & 84.04 & 13.32 \\
\hline 4 & 1.72 & 87.15 & 11.13 & 34 & 3.14 & 72.12 & 24.74 \\
\hline 5 & 1.32 & 79.94 & 18.74 & 35 & 2.64 & 74.63 & 22.73 \\
\hline 6 & 2.23 & 76.98 & 20.79 & 36 & 2.13 & 76.08 & 21.79 \\
\hline 7 & 1.79 & 78.73 & 19.48 & 37 & 1.83 & 81.38 & 16.80 \\
\hline $\mathbf{8}$ & 6.32 & 80.39 & 13.29 & 38 & 1.22 & 77.44 & 21.34 \\
\hline 9 & 1.51 & 82.13 & 16.36 & 39 & 1.81 & 77.86 & 20.33 \\
\hline 10 & 3.66 & 74.40 & 21.94 & 40 & 2.44 & 80.02 & 17.54 \\
\hline 11 & 2.00 & 81.74 & 16.26 & 41 & 2.20 & 76.10 & 21.70 \\
\hline 12 & 1.64 & 86.26 & 13.74 & 42 & 3.68 & 73.39 & 22.93 \\
\hline 13 & 2.43 & 80.91 & 16.66! & 43 & 2.98 & 73.14 & 23.88 \\
\hline 14 & 3.52 & 69.64 & 26.84 & 44 & 1.84 & 79.40 & 18.76 \\
\hline 15 & 3.77 & 76.64 & 19.59 & 45 & 2.76 & 78.43 & 18.81 \\
\hline 16 & 1.34 & 71.35 & 27.31 & 46 & 2.72 & 82.64 & 14.64 \\
\hline 17 & 2.58 & 68.53 & 28.89 & 47 & 1.04 & 74.62 & 24.34 \\
\hline 18 & 2.42 & 83.22 & 14.36 & 48 & 3.36 & 74.71 & 21.93 \\
\hline 19 & 1.51 & 85.66 & 12.83 & 49 & 4.19 & 76.36 & 19.45 \\
\hline 20 & 2.56 & 79.62 & 17.82: & 50 & 3.67 & 78.75 & 17.58 \\
\hline 21 & 2.39 & 77.07 & 20.00 & 51 & 1.44 & 85.83 & 12.73 \\
\hline 22 & 2.69 & 80.95 & 16.36 & 52 & 1.29 & 79.24 & 19.47 \\
\hline 23 & 2.52 & 71.79 & 25.69 & 53 & 1.41 & 81.24 & 17.35 \\
\hline 24 & 2.62 & 73.70 & 23.68 & 54 & 3.82 & 73.35 & 22.83 \\
\hline 25 & 1.98 & 78.46 & 19.56 & 55 & 2.03 & $\mathbf{8 1 . 3 0}$ & 16.67 \\
\hline 26 & 5.52 & 76.29 & 18.19: & 56 & 2.30 & 82.49 & 15.21 \\
\hline 27 & 2.26 & 79.97 & 21.07 & 57 & 1.64 & 74.03 & 24.33 \\
\hline 28 & 1.73 & 83.97 & 14.30 & 58 & 1.82 & 81.90 & 16.28 \\
\hline \multirow{4}{*}{30} & 3.06 & 71.60 & 25.34 & 59 & 2.53 & $\begin{array}{l}76.61 \\
79.06\end{array}$ & 20.86 \\
\hline & 1.78 & 81.91 & 16.31 & $\begin{array}{l}\text { 60 } \\
\text { Min. }\end{array}$ & $\begin{array}{l}1.22 \\
1.04\end{array}$ & $\begin{array}{l}79.06 \\
68.53\end{array}$ & $\begin{array}{l}19.72 \\
11.13\end{array}$ \\
\hline & & & & Max. & 6.32 & 87.15 & 28.89 \\
\hline & & & & Average & 2.43 & 78.41 & 19.23 \\
\hline
\end{tabular}




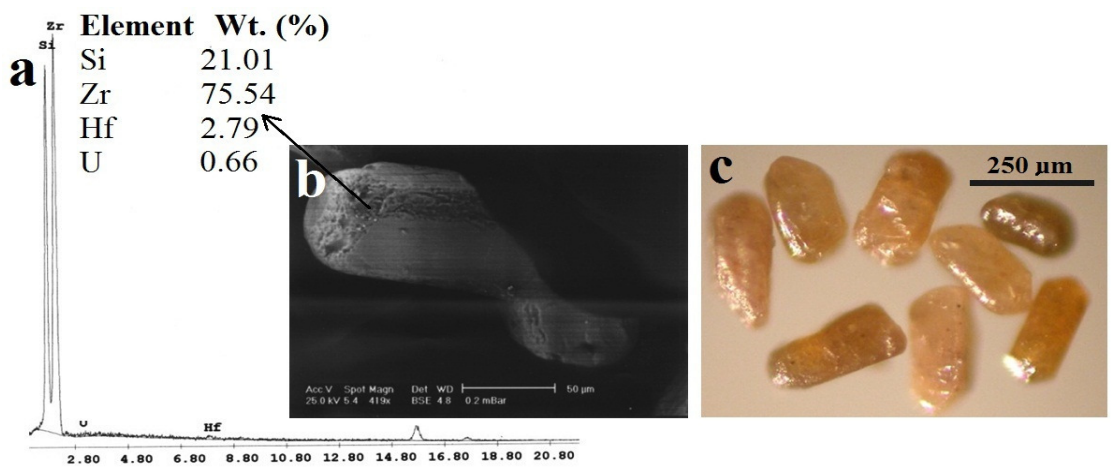

Fig. 5: Coloured zircon crystals EDX analysis (a), ESEM backscattered image (b) and zircon crystals under binocular microscope $(\mathrm{c}), \mathrm{X}=10$.

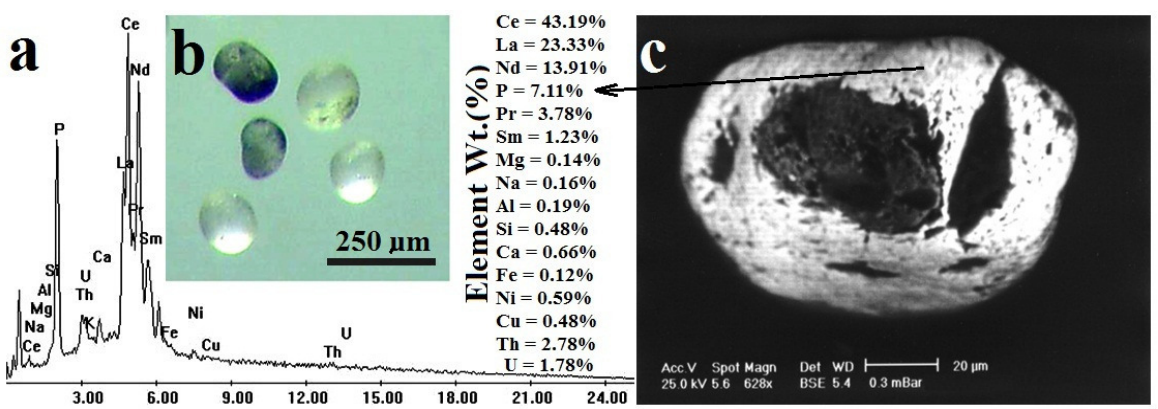

Fig. 6: EDX analysis (a), binocular microscope $(X=20)$ photo of monazite crystals $(b)$ and ESEM backscattered image (c).

The content of the heavy economic minerals was found to attain $0.54 \%$ magnetite, $0.2 .88 \%$ ilmenite, $0.23 \%$ leucoxene, $0.80 \%$ garnet, $0.39 \%$ zircon, $0.15 \%$ rutile and $0.008 \%$ monazite (Table 3). The radioactive level of zircon accepted for use in the domestic purposes such as ceramic is U+Th less than 500 ppm (Elder and Domenico, 2000). Monazite is a major source of thorium and rare earth elements (including lanthanum, cerium, neodymium and yttrium) in the heavy mineral sand deposits. Monazite contains approximately $46 \%$ Ce, $18 \% \mathrm{Nd}, 2 \% \mathrm{Yt}, 28 \%$ other Cerics and 6\% other Yttrics (Tourre, 1999). Rare earths applications market are as the following: catalysis $15 \%$, metal and alloys $44 \%$, electronic $16 \%$, materials $21 \%$ and $4 \%$ others (Tourre, 1999).
Radioactivity of the studied area is attributed to the occurrences of high relative concentrations of radioactive U- and/or Thbearing minerals such as monazite and zircon. The radiometric measurements for the economic minerals of the studied samples showed that these minerals have low radioactive level that makes them become accepted for use in the domestic purposes (product of $\mathrm{TiO}_{2}$, ceramics, water get, ... etc) and become more attractive to the local and world marketing

\section{Ground Spectrometric Survey}

The ground spectrometric survey includes ground TC radiometric and spectrometric survey at certain group of 861 stations (Figs.4 \& 16 ). The measurements are 
Table 3: Mineralogical constituents of 60 representative samples (heavy liquids)

\begin{tabular}{|c|c|c|c|c|c|c|c|c|c|c|c|c|c|c|c|c|c|}
\hline No. & Mag. & Im. & Leuc. & Gar. & Zir. & Rut. & Mon. & To & & Mag. & IIm & c. & Gar. & Gir. & Rut. & Mon. & Tot \\
\hline$\overline{1}$ & $\overline{0.42}$ & 1.75 & $\overline{0.34}$ & $\overline{0.60}$ & 26 & $\begin{array}{l}0.09 \\
\end{array}$ & $\overline{0.010}$ & 3.470 & 31 & 0.52 & 3.05 & 0.44 & .72 & 0.36 & $\overline{0.08}$ & $\overline{0.011}$ & $\overline{5.181}$ \\
\hline 2 & 0.39 & 3.02 & 0.21 & 0.86 & 0.42 & 0.16 & 0.013 & 5.073 & 32 & 38 & 2.12 & 0.24 & 84 & 0.32 & 0.15 & 0.003 & 4.053 \\
\hline 3 & 0.64 & .93 & 0.22 & 0.77 & 0.34 & 0.14 & 0.012 & 6.052 & 33 & 64 & 3.33 & 0.25 & 89 & 0.36 & 0.16 & 0.017 & 5.647 \\
\hline 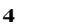 & 0.73 & 2.31 & 0.21 & 0.69 & 0.37 & 0.11 & 0.011 & 4.431 & 34 & 0.62 & 2.75 & 0.32 & 0.59 & 0.31 & 0.09 & 0.006 & 4.686 \\
\hline 5 & 0.35 & 2.62 & 0.15 & 0.82 & 0.37 & 0.17 & 0.006 & 4.486 & 35 & 0.32 & 1.95 & 0.22 & 0.44 & 0.46 & 0.06 & 0.006 & 3.456 \\
\hline 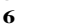 & 0.33 & 3.64 & 0.14 & 0.79 & 0.37 & 0.12 & 0.011 & 5.401 & 36 & .28 & 3.28 & 0.18 & 0.82 & 0.39 & 0.11 & 0.007 & 5.067 \\
\hline 7 & 0.37 & 1.97 & 0.18 & 0.80 & 0.27 & 0.11 & 0.009 & 3.709 & 37 & 0.46 & 2.24 & 0.17 & 1.21 & 0.56 & 0.15 & 0.012 & 4.802 \\
\hline 8 & 0.74 & 3.23 & 0.24 & 0.99 & 0.35 & 0.12 & 0.016 & 5.686 & 38 & .58 & 3.04 & 0.19 & 1.08 & 0.67 & 0.14 & 0.010 & 5.710 \\
\hline 9 & 0.57 & 3.04 & 0.16 & 1.06 & 0.47 & 0.16 & 0.012 & 5.472 & 39 & 0.60 & 1.48 & 0.22 & 0.70 & 0.39 & 0.17 & 0.005 & 3.565 \\
\hline 10 & 0.49 & 3.46 & 0.19 & 0.75 & 0.44 & 0.14 & 0.006 & 5.476 & 40 & .53 & .41 & 0.34 & 0.75 & 0.33 & 0.20 & 0.011 & 4.571 \\
\hline 11 & 0.96 & 4.02 & 0.35 & 1.50 & 0.73 & 0.27 & 0.011 & 7.841 & 41 & 0.81 & 4.21 & 0.22 & 0.76 & 0.46 & 0.26 & 0.004 & 6.724 \\
\hline 12 & 0.47 & 2.04 & 0.16 & 1.01 & 0.57 & 0.18 & 0.014 & 4.444 & 42 & 0.37 & 3.62 & 0.15 & 0.83 & 0.45 & 0.14 & 0.005 & 5.565 \\
\hline 13 & 0.42 & 1.65 & 0.12 & 0.50 & 0.36 & 0.05 & 0.004 & 3.104 & 43 & 0.33 & 2.54 & 0.22 & 0.73 & 0.36 & 0.15 & 0.002 & 4.332 \\
\hline 14 & 0.91 & 4.41 & 0.12 & 0.96 & 0.56 & 0.22 & 0.014 & 7.194 & 44 & 0.63 & 2.30 & 0.20 & 0.67 & 0.37 & 0.11 & 0.010 & 4.290 \\
\hline 15 & 0.63 & 2.61 & 0.33 & 0.77 & 0.32 & 0.10 & 0.010 & 4.770 & 45 & 31 & 13 & 0.20 & 0.86 & 0.46 & 0.13 & 0.013 & 4.903 \\
\hline 16 & & 34 & 0.20 & 0.67 & 0.37 & 0.14 & 0.010 & 4.170 & 46 & & & & 0.76 & 0.36 & 0.12 & 0.011 & 5.341 \\
\hline 17 & 0.50 & 2.41 & 0.21 & 0.77 & 0.36 & 0.12 & 0.004 & 4.374 & 47 & .53 & .14 & 0.33 & 0.84 & 0.33 & 0.17 & 0.010 & 5.350 \\
\hline 18 & 0.4 & 2.54 & 0.24 & 0.78 & 0.36 & 0.14 & 0.012 & 4.502 & 48 & 26 & 3.27 & 19 & 87 & 37 & 10 & 06 & 5.066 \\
\hline 19 & 0.59 & 3.36 & 09 & 0.65 & 0.24 & 0.11 & 0.008 & 5.048 & 49 & 48 & 2.02 & 0.33 & 0.70 & 0.32 & 0.12 & 0.002 & 3.972 \\
\hline 20 & 0.86 & 4.12 & 0.32 & 1.20 & 0.75 & 0.26 & 0.012 & 7.522 & 50 & 0.46 & 3.67 & 0.26 & 0.88 & 0.35 & 0.12 & 0.006 & 5.746 \\
\hline 21 & 0.44 & 1.85 & o & 0.63 & 0.26 & 0.08 & 0.010 & 3.510 & 51 & & 3. & 20 & 0.63 & 25 & 0.12 & 11 & 5.671 \\
\hline 22 & 0.54 & 3.14 & 0.30 & 0.74 & 0.30 & 0.16 & 0.010 & 5.190 & 52 & 0.86 & 4.12 & 0.25 & 1.44 & 0.66 & 0.28 & 0.011 & 7.621 \\
\hline 23 & & 2.96 & & 0.83 & 0.24 & 0.18 & 0.009 & 4.859 & 53 & & & & 55 & & 16 & & 5.346 \\
\hline 24 & 0 & 2.27 & 0 & 0.73 & 0.17 & 0.10 & 0.008 & 3.838 & 54 & 53 & 2. & 0.26 & 0.72 & 0.37 & .16 & 0.006 & 4.736 \\
\hline 5 & & 2.88 & 0.2 & 0.73 & 0.22 & 0.12 & 0.011 & 4.861 & 55 & 50 & 2 & 0.34 & 0.62 & 35 & 11 & 0.010 & 4.280 \\
\hline 26 & & & 0.2 & 076 & 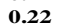 & 0.24 & 0.002 & & 56 & & & & & 41 & 08 & 0.007 & 4.747 \\
\hline 27 & 0.45 & 3.67 & 0.26 & 0.78 & 0.36 & 0.14 & 0.005 & 5.665 & 57 & 42 & 35 & 0.21 & 0.62 & 0.47 & 14 & 0.010 & 4.220 \\
\hline 28 & & 2.43 & & 0.67 & .35 & 0.13 & 0.005 & 4.305 & 58 & & & & 10 & 0.65 & 24 & 02 & 6.262 \\
\hline 29 & o & 2.02 & 0.31 & 0.80 & 0.32 & 0.10 & 0.012 & 4.052 & 5 & & 2 & 0.09 & 0.66 & .34 & .11 & 0.007 & 4.117 \\
\hline 30 & 0.81 & 2.44 & 0.22 & 0.87 & 0.46 & 0.13 & 0.013 & 4.943 & 60 & 0.48 & 3.84 & 0.18 & 0.73 & 0.33 & 0.17 & 0.008 & 5.738 \\
\hline \multirow{3}{*}{\multicolumn{9}{|c|}{$\begin{array}{l}\text { Mag. = Magnetite, }, \mathbf{I m}=\text { Imenite, } \text { Leuc. }=\text { Leucoxene, } \\
\text { Gar. = Garnet, Zir. = Zircon, Rut. = Rutile, Mon. = Monazite and } \\
\text { Total = Total heavy minerals. }\end{array}$}} & Mir & 0.26 & 1.85 & 0.09 & 0.44 & 0.17 & 0.06 & 0.002 & 3.46 \\
\hline & & & & & & & & & Max & .8 & 4.21 & 0.34 & 1.44 & 0.67 & 0.28 & 0.017 & 7.62 \\
\hline & & & & & & & & & Ave. & 0.54 & 2.88 & 0.23 & 0.80 & 0.39 & 0.15 & 0.008 & 5.00 \\
\hline
\end{tabular}

normally attributed to the apparent surface potassium-40 percentage $\left(\mathrm{K}^{40 \%} \%\right)$, equivalent uranium content ( $\mathrm{eU}$ in $\mathrm{ppm})$, and equivalent thorium content (eTh in $\mathrm{ppm}$ ), in addition to their total gamma-ray $(\gamma)$ response (TC in $\mu \mathrm{R} /$ h). Each of these measured variables is presented as a colored contour map as follows: total count of gamma radiation ( $\mathrm{TC}$ in $\mu \mathrm{R} / \mathrm{h}$ ) is presented on Fig.7, absolute concentration of the three radio-elements potassium $(\mathrm{K}$ in $\%$ ), equivalent uranium in ppm and equivalent thorium in ppm are presented on Figs.8,9 and 10. The measuring time was set up at 30 seconds to permit the accumulation of the $\gamma$-ray emission to be measured accurately as possible. The data were directly stored in the field and dumped daily to the computer at the office. Examination of the spectrometric measurements in the study area revealed that the concentrations of the three natural radioelements $\mathrm{K}, \mathrm{U}$ and $\mathrm{Th}$. These ranged from 0.0 to $2.3 \% \mathrm{ppm}, 0.0$ to $3.6 \mathrm{ppm}$ and 0.7 to $17.7 \mathrm{ppm}$, respectively. The average (mean background) values of these radio-elements were $1.034 \%$ for $\mathrm{K}, 1.34 \mathrm{ppm}$ for $\mathrm{U}$ and 7.5 for Th.

The qualitative interpretation of the ground gamma-ray spectrometric survey data depends mainly upon the excellent correlation between the general pattern of the recorded measurements and the surface distribution of the various heavy mineral deposits. The texture of the radio-spectrometric contour lines (signatures) could be an aid in the course of interpretation of the surface geology. The observed variations in the spatial distribution of the absolute concentrations of thorium and uranium give an overall picture of the distribution of the surficial heavy mineral concentrations in the investigated mineral sand beach deposits, as inferred from the qualitative interpretation of the two main radio-elements. This is consistent with the depositional history of these mineral deposits as described by many other authors; Dabbour (1980), El Shazly et al. (1984), Dabbour et al. (1988) and Abdelhady et al. (2004). 


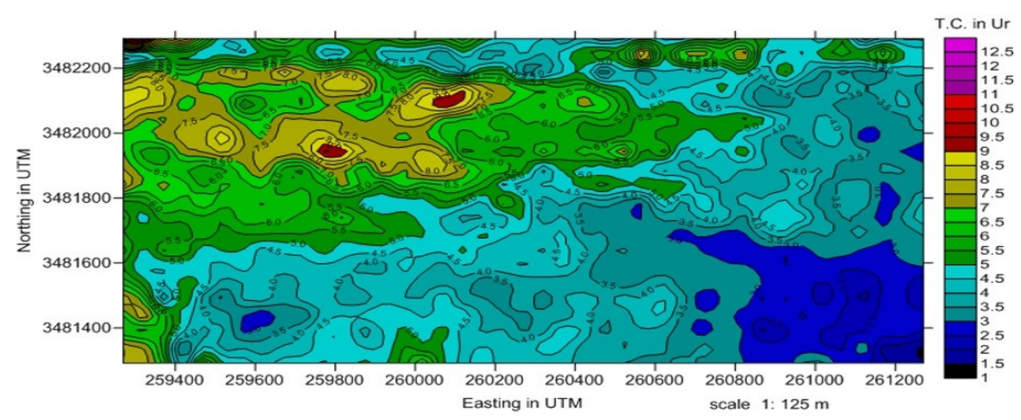

Fig. 7: Ground radiometric distribution contour map of total count in $(\mu \mathrm{R})$ of the study area

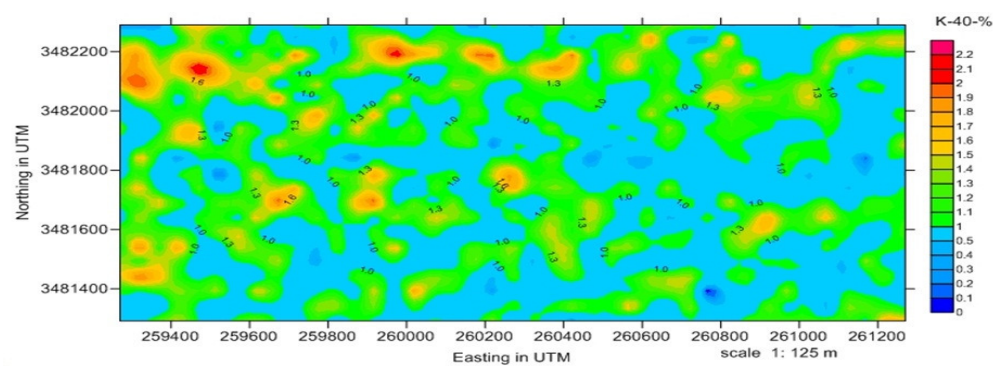

Fig. 8: Ground radiometric distribution contour map of potassium $\%$ of the study area

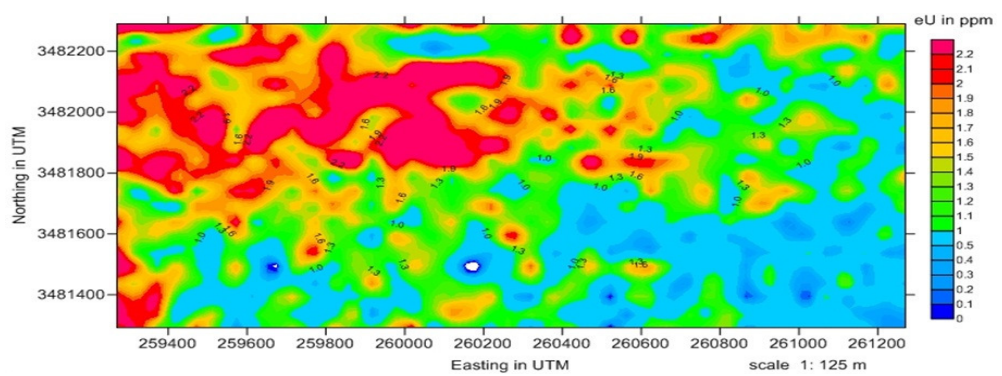

Fig. 9: Ground radiometric distribution contour map of eU(ppm) of the study area

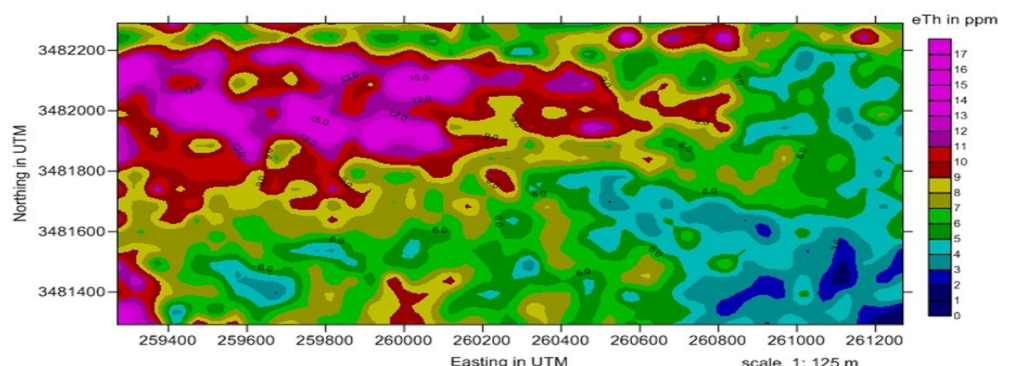

Fig. 10: Ground radiometric distribution contour map of $\stackrel{\text { scale } 1: 125 \mathrm{~m}}{\mathrm{eTh}}(\mathrm{ppm})$ of the study area 
Close visual examination of the airborne gamma-ray spectrometric filled-color contour maps of the surveyed area (Fig. 2) indicated that the outlined radio-spectrometric pattern consists of four zones. These results agree with the more detailed ground gamma-ray survey. The total radiometric (TC, Fig.7) and the three radio-spectrometric maps $\mathrm{K} \%$, eU ppm and eTh maps (Figs. 8, 9 and 10) indicate that most of the study area is characterized by low total radioactivity as well as the three radioactive elements (can be distinguished by blue and green colours). Also, these maps show a relatively high radioactivity zone in the northwestern part of the study area, in addition to some of small zones in the north and west of the study area. This zone must be taken into consideration during the exploitation of the proposed area.

\section{Statistical analysis of the ground detailed radio-spectrometric data}

The results of the qualitative interpretation of the gamma ray spectrometric data acquired over the investigated mineral sand beach deposits of the study area have been quantified through the application of standard statistical analysis techniques. Filled color contour maps for TC, K, eU and eTh were plotted for the detailed survey area. The number of valid data points per element was 861 points. Standard statistics were applied to the data to compute the mean (X) and standard deviations (S) for each variable (Table 4).

\section{Laboratory Radiometric Analysis}

Table (5) shows the radioelement contents of both eU and eTh in ppm for each soil subsurface samples taken at $50 \mathrm{~cm}$ depth in representing sites of the study area. Contents of $\mathrm{K}$ values are under the limit of detection far most of these samples. In addition the amount

Table 4: Descriptive statistics of the ground gamma ray spectrometric survey data of Metoubas area, Mediterranean coast, Egypt

\begin{tabular}{lrrrr}
\hline & $\mathrm{TC}(\mu \mathrm{R})$ & $\mathrm{K}(\%)$ & $\mathrm{eU}(\mathrm{ppm})$ & $\mathrm{eTh}(\mathrm{ppm})$ \\
\hline Number of data points & 861 & 861 & 861 & 861 \\
Minimum & 1.3 & 0 & 0 & 0.7 \\
Maximum & 12.2 & 2.3 & 3.6 & 17.7 \\
Mean & 4.8 & 1.03 & 1.3 & 7.48 \\
Standard deviation & 1.65 & 0.39 & 0.7 & 3.04 \\
\hline
\end{tabular}

Table 5: Laboratory radiometric measurements of the site samples

\begin{tabular}{|c|c|c|c|c|c|c|c|c|c|c|c|c|c|}
\hline $\begin{array}{l}\text { S. } \\
\text { No. }\end{array}$ & $\begin{array}{r}\text { E in } \\
\text { UTM } \\
\end{array}$ & $\begin{array}{r}\mathbf{N} \text { in } \\
\text { UTM } \\
\end{array}$ & $\begin{array}{r}\text { eU } \\
\text { ppm) }\end{array}$ & $\begin{array}{r}\text { eTh } \\
\text { (ppm) } \\
\end{array}$ & $\mathbf{R a}$ & $\begin{array}{r}\mathbf{K} \\
(\%)\end{array}$ & $\begin{array}{l}\text { S. } \\
\text { No. }\end{array}$ & $\begin{array}{r}\text { E in } \\
\text { UTM } \\
\end{array}$ & $\begin{array}{r}\mathbf{N} \text { in } \\
\text { UTM } \\
\end{array}$ & $\begin{array}{r}\text { eU } \\
\text { (ppm) }\end{array}$ & $\begin{array}{r}\text { eTh } \\
(\mathbf{p p m}) \\
\end{array}$ & $\mathbf{R a}$ & $(\%$ \\
\hline 1 & 261120 & 3482240 & 4.95 & 3.04 & 1.97 & ULD & 31 & 260195 & 3481741 & 3.01 & 9.95 & 2.99 & ULD \\
\hline 2 & 261120 & 3482190 & 3.46 & 6.04 & 1.16 & ULD & 32 & 260195 & 3481691 & 3.54 & 7.32 & 2.049 & ULD \\
\hline 3 & 261120 & 3482140 & 2.11 & 3.10 & 0.96 & ULD & 33 & 260195 & 3481641 & 5.00 & 6.02 & 1.009 & ULD \\
\hline 4 & 261120 & 3482090 & 4.98 & 3.04 & 2.00 & ULD & 34 & 260195 & 3481591 & 3.68 & 7.29 & 2.329 & ULD \\
\hline 5 & 261120 & 3482040 & 2.91 & 5.73 & 1.30 & ULD & 35 & 260195 & 3481541 & 3.15 & 6.89 & ULD & ULD \\
\hline 6 & 261120 & 3481991 & 2.07 & 3.07 & 0.97 & ULD & 36 & 260195 & 3481492 & 5.00 & 7.02 & 1.009 & ULD \\
\hline 7 & 261120 & 3481941 & 4.48 & 4.04 & 2.00 & ULD & 37 & 260195 & 3481442 & 4.34 & 4.63 & 1.66 & ULD \\
\hline 8 & 261120 & 3481891 & 2.63 & 6.40 & 1.56 & ULD & 38 & 260195 & 3481392 & 2.78 & 7.11 & 2.27 & ULD \\
\hline 9 & 261120 & 3481841 & 2.03 & 3.04 & 0.99 & ULD & 39 & 260195 & 3481342 & 5.00 & 7.97 & 1.00 & ULD \\
\hline 10 & 261120 & 3481791 & 4.06 & 5.07 & 2.00 & ULD & 40 & 260195 & 3481292 & 4.99 & 2.06 & 1.01 & JLD \\
\hline 11 & 261120 & 3481741 & 2.71 & 7.31 & 1.81 & ULD & 41 & 259270 & 3482240 & 3.45 & 6.99 & 2.12 & ULD \\
\hline 12 & 261120 & 3481691 & 2.00 & 3.10 & 1.00 & ULD & 42 & 259270 & 3482190 & 4.95 & 6.03 & 1.01 & ULD \\
\hline 13 & 261120 & 3481641 & 5.72 & 7.07 & 2.00 & ULD & 43 & 259270 & 3482140 & 3.99 & 7.10 & 2.03 & ULD \\
\hline 14 & 261120 & 3481591 & 3.08 & 7.45 & 1.95 & ULD & 44 & 259270 & 3482090 & 4.98 & 6.72 & ULD & ULD \\
\hline 15 & 261120 & 3481541 & 2.00 & 6.10 & 1.00 & ULD & 45 & 259270 & 3482040 & 1.01 & $\mathbf{0}$ & 2.00 & JLD \\
\hline 16 & 261120 & 3481492 & 7.38 & 9.06 & 2.00 & ULD & 46 & 259270 & 3481991 & 3.00 & 15.98 & 5.00 & ULD \\
\hline 17 & 261120 & 3481442 & 3.58 & 7.09 & 2.02 & o.01 & 47 & 259270 & 3481941 & 5.91 & 6.66 & 1.70 & 0.01 \\
\hline 18 & 261120 & 3481392 & 2.01 & 8.98 & 1.01 & ULD & 48 & 259270 & 3481891 & 2.35 & 8.34 & 1.66 & LLD \\
\hline 19 & 261120 & 3481342 & 9.00 & 10.99 & ULD & ULD & 49 & 259270 & 3481841 & 3.34 & 13.65 & 4.33 & ULD \\
\hline 20 & 261120 & 3481292 & 4.00 & 6.77 & 2.07 & ULD & 50 & 259270 & 3481791 & 6.13 & 6.77 & 1.52 & ULD \\
\hline 21 & 260195 & 3482240 & 2.25 & 8.24 & 1.26 & ULD & 51 & 259270 & 3481741 & 3.68 & 8.67 & 1.33 & JLD \\
\hline 22 & 260195 & 3482190 & 9.00 & 10.49 & 2.00 & ULD & 52 & 70 & 3481691 & 3.67 & 11.32 & 3.66 & ULD \\
\hline 23 & 260195 & 3482140 & 4.08 & 7.1 & 2.18 & ULD & 53 & 259 & 3481641 & 6.09 & 6.93 & 1.36 & JLD \\
\hline 24 & 260195 & 3482090 & 2.50 & 7.49 & 1.51 & ULD & 54 & 259270 & 3481591 & 5.00 & 8.98 & 1.00 & JLD \\
\hline 25 & 26019 & 3482 & 9.0 & 10. & 2.00 & ULD & 55 & 259 & 3481541 & 0.01 & 9.00 & 3.00 & ULD \\
\hline 26 & 260195 & 3481991 & 3.72 & 8.2 & 2.32 & ULD & 56 & 259270 & 3481492 & 6.01 & 7.04 & 1.25 & ULD \\
\hline 27 & 260195 & 3481941 & 2.75 & 6.7 & 1.76 & ULD & 57 & 259270 & 3481442 & 6.00 & 3.00 & 1.00 & ILD \\
\hline 28 & 26015 & 348 & 8. & 14. & 2.02 & ULD & 58 & 25 & 1392 & 4.01 & & 3.01 & ULD \\
\hline 29 & 260195 & 3481841 & 3.48 & 8.4 & 2.26 & ULD & 59 & 259270 & 3481342 & 5.96 & 7.09 & 1.21 & ULD \\
\hline 30 & 260195 & 3481791 & .04 & 6.00 & 1.98 & ULD & 60 & 259270 & 3481292 & 6.04 & 3.09 & 1.00 & ULD \\
\hline
\end{tabular}


of radon emissions as equivalent eU ppm are detected for each sample.

Table (5) shows laboratory radiometric measurements and the corresponding radiospectrometric measurements at each sample soil site. Figures 11, 12 and 13 show the eU, eTh and radon (eU ppm) levels, respectively. These maps are constructed from sample analysis and are represented as contour maps. The table and maps define the upper surface distribution of the radio-elements rather than the expected degree of radon emission up to the ground surface. They indicate that the proposed area is characterized by low radio- element content in general except at two limited zones in the west and the north of the area, in light of the eU contour map and another limited zone of relatively high thorium content at the center of the study area.

\section{Dose rate calculations}

In the Standard International (SI) units (Roentgen) is equivalent Man "rem" has been replaced by the Sievert where, $1 \mathrm{~Sv}=$ $100 \mathrm{rem}$. The rem unit is the biological effect of the dose of any radiation (in rad or Gray). To outline their biological effect of specific types of radiation, the absorbed dose

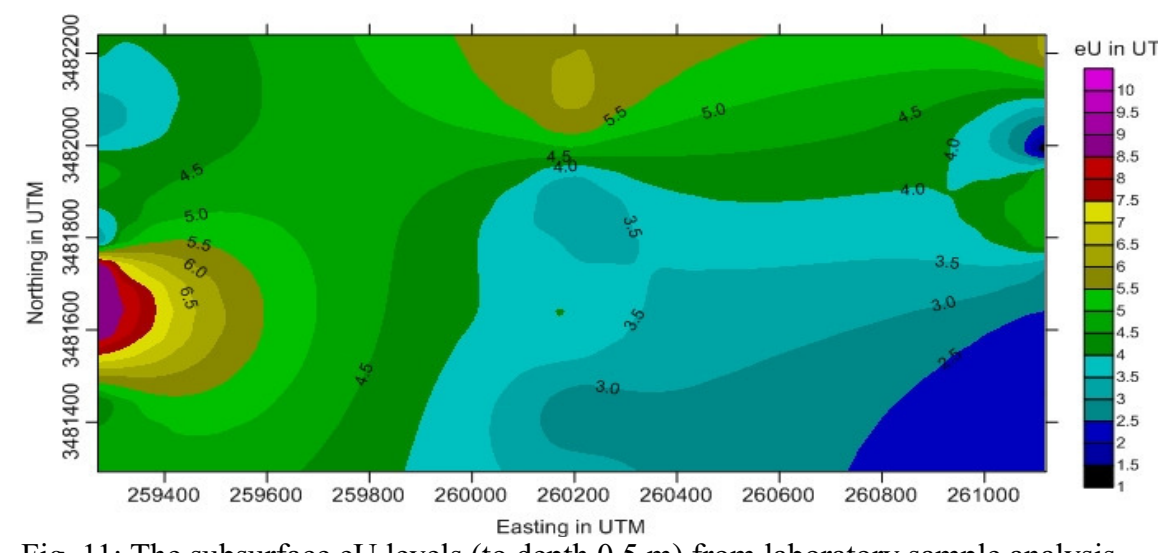

Fig. 11: The subsurface eU levels (to depth $0.5 \mathrm{~m}$ ) from laboratory sample analysis

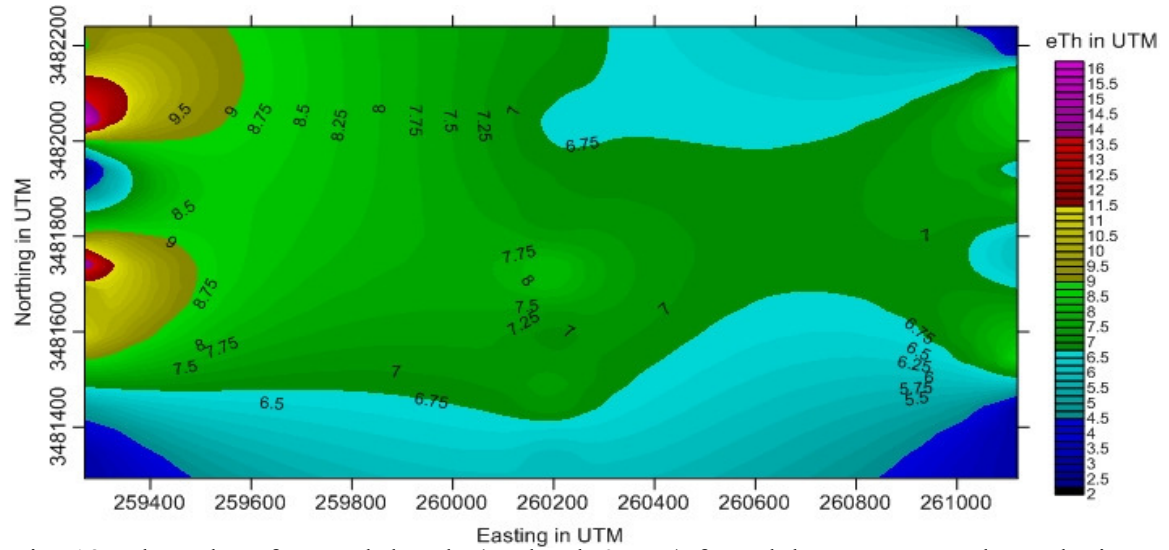

Fig. 12: The subsurface eTh levels (to depth $0.5 \mathrm{~m}$ ) from laboratory sample analysis 


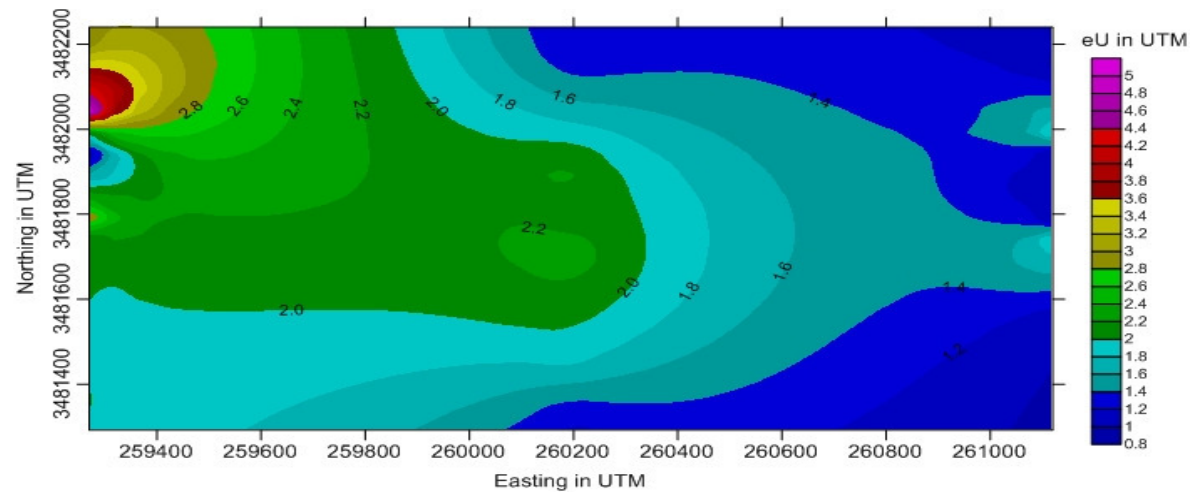

Fig. 13: The subsurface Radium (eU) levels in the depth of $0.5 \mathrm{~m}$ from laboratory sample analysis

in rad must be multiplied by a certain factor "quality factor, Q", which then shows the dose in rems.

$\mathrm{X}$-rays and gamma rays have a $\mathrm{Q} \approx 1$, so the absorbed dose in rads is the same number in rems. (For contrast: Neutrons have a Q of about 5 and alpha particles have a $Q$ of about 20. Sievert "Sv" is a unit measuring absorption of radiation by tissue (equivalent doses). To express all radiation doses in a single unit, the microsievert ( $\mu \mathrm{Sv})$ to make comparisons easier when possible (IAEA, 1979).

The statistical parameters of the estimated dose rate, in millie Sievert (mSv), from the obtained $\mathrm{K} \%$ and $\mathrm{eU}$ and $\mathrm{eTh}$ concentrations
(Fig. 14) are illustrated in Table (6). Also, Figure (15) shows the dose rate contour map of the study area in $\mathrm{mSv} / \mathrm{y}$.

\section{Exposure Rate Calculations}

In order to determine the average exposure rate of the exterior penetrating gammaradiation arising from the natural terrestrial sources in study area, the average concentrations of the three radio-elements $\mathrm{U}$, Th and $\mathrm{K}$ were converted into activity per unit time as follows:

$$
\begin{aligned}
& \text { Average exposure rate }= \\
& (1.3 \mathrm{U} \mathrm{ppm} \times 0.62 \mu \mathrm{R} / \mathrm{h})+(7.5 \mathrm{Th} p m \times 0.31 \mu \mathrm{R} / \mathrm{h}) \\
& +(1.034 \mathrm{~K} \% \times 1.5 \mu \mathrm{R} / \mathrm{h})=4.682 \mu \mathrm{R} / \mathrm{h} .
\end{aligned}
$$

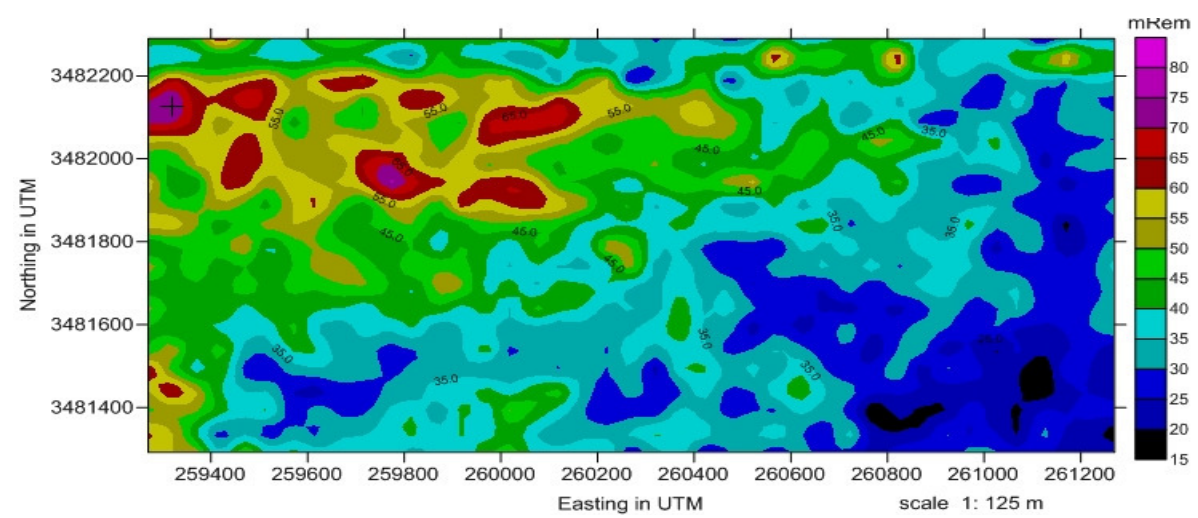

Fig. 14: Exposure rate contour map of the study area in $\mathrm{mRem} / \mathrm{y}$ 


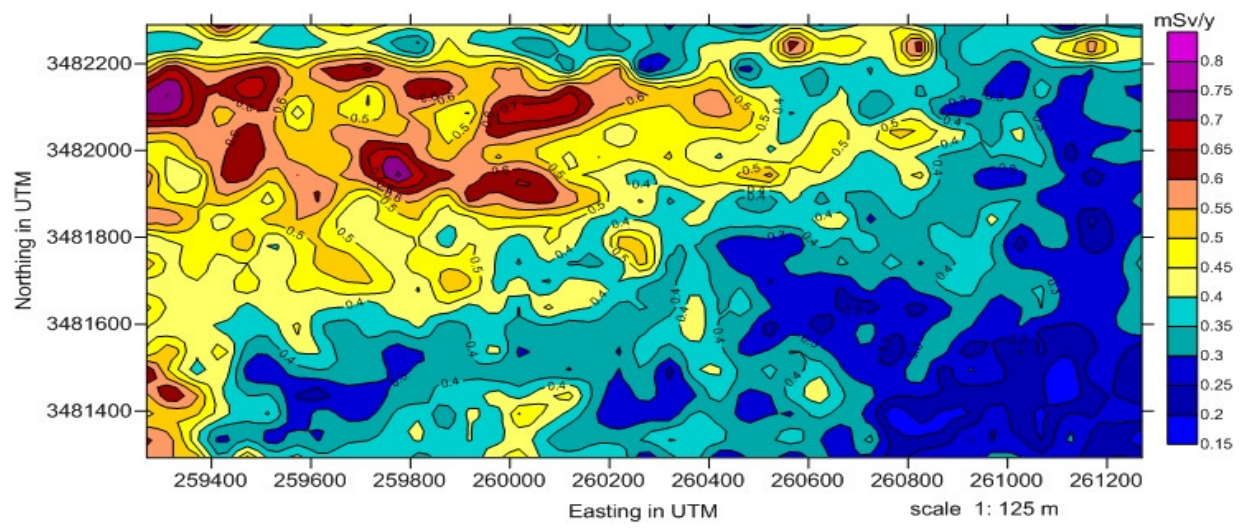

Fig. 15: Dose rate contour map of the study area in $\mathrm{mSv} / \mathrm{y}$

Table 6: Means of the natural dose rates $(\mathrm{mSv} /$ y) over the ground surface of the proposed area

\begin{tabular}{lr}
\hline Statistical parameter & The value \\
\hline Number of data points & $\mathbf{8 6 1}$ \\
Minimum & $\mathbf{0 . 1 3 0 7 8 1}$ \\
Maximum & $\mathbf{0 . 7 7 1 3 5 8}$ \\
Mean & $\mathbf{0 . 3 9 2 7 7 2}$ \\
Standard deviation & $\mathbf{0 . 1 1 6 0 3 4}$ \\
\hline
\end{tabular}

The computed average exposure rate value $4.682 \mu \mathrm{R} / \mathrm{h}$ represents the average environmental terrestrial radioactivity level in the study area. This value can be used as a reference to detect and determine the amount and extent of any possible future environmental variation in the natural terrestrial radioactivity level in this area that might result from natural or artificial sources. Accordingly, a periodical systematic surveying is recommended for monitoring any changes in environmental radioactivity level that might occur in the area.

Figure (14) shows the exposure rate contour map of the study area in $m R e m / y$. These sources of exposure to radiation are, by all sources of radioactivity pollution includes: terrestrial radioactive nuclides, radiation in the air, cosmic radiation, radioactivity in water etc, within the permissible dose.

\section{The Results Of Radio-Spectrometric And Dose Rate}

The radiation doses received by people are frequently measured in "rems". For gammaradiation, the conversion from exposure rate to dose rate is: $1 \mu \mathrm{R} / \mathrm{h}=8.33$ millirems/year. The international Commission of Radiological Protection (ICRP) has recommended that no individual should receive more than 5000 millirems/year $(50 \mathrm{mSv} / \mathrm{y})$ from all natural and artificial radiation sources in his or her environment (IAEA, 1979).

In the study area, the mean natural dose rate from the terrestrial gamma-radiation, to which individuals are exposed, was computed as about 39.3 millirems/year $(0.393 \mathrm{mSv} / \mathrm{y})$. This value remains in the safe side and much less than the maximum permissible safe radiation dose to the individual (IAEA, 1979), with continuous external irradiation of the whole body.

Mainly, the radioactivity values remain within the safe limit and much less than the maximum permissible safe radiation dose to the individual, with continuous external irradiation of the whole body. The ground radio-spectrometric (Figs. 7-10) and the dose rate maps (Figs. $14 \& 15$ ) as well as the point anomaly map (Fig. 16) show the distribution and levels of the radioactivity and dose rate on the surface of the area. These figures and tables 


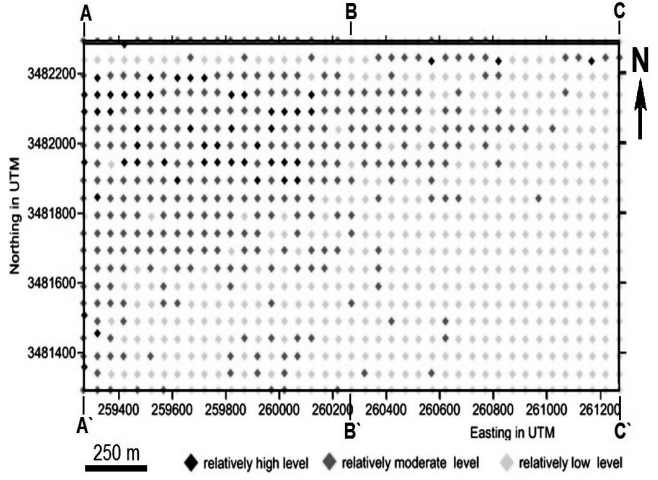

Fig. 16: The point anomaly map of the different dose rate levels at the different stations $(50 \mathrm{~m}$ in-betweens) of the study area in $m R e m / y$. The three profiles (A-A', B-B' and C-C') were used to collect field borehole samples

(5 and 6) delineate that the area can be classified into three radioactive levels, relatively high radioactivity, moderate radioactivity and low radioactivity. The average dose rate values are classified relatively into three levels, high, moderate and low, $0.66 \mathrm{mSv} / \mathrm{y}, 0.48$ $\mathrm{mSv} / \mathrm{y}$ and $0.31 \mathrm{mSv} / \mathrm{y}$, respectively.
Relationship Between Mineralogy And Radioactivity

The relationship between mineralogy and radioactivity is complex due to different variables affecting it. From the mineralogical study, there are two major minerals emit radioactivity, i.e. zircon and thorium (Figs. 5 and 6). Both minerals are representing a small amount from the total heavies (wt.\%) especially the monazite (Table 3). The correlation between their lateral variations versus eU and eTh are illustrated on Fig. (17).

The following notes can be established from Figure (17):

\section{Profile $A-A$}

Both curves of eU and eTh show similarity in most of this profile, this may means that both u-bearing and Th-bearing minerals are presented in this profile. Also, monazite and zircon distribution curves are similar in most portion of the profile except some portions (samples 5 and 17). The radioactivity in this profile

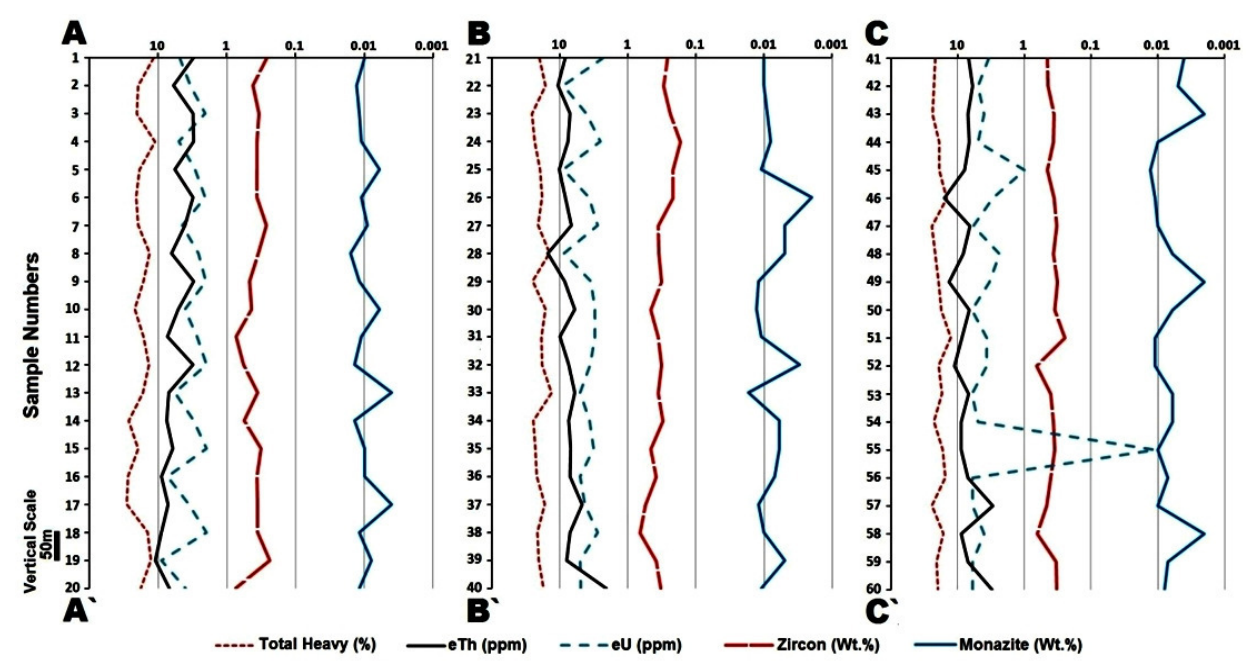

Fig. 17: Lateral variation diagram of zircon (\%), monazite (\%), eU (ppm) and eTh (ppm) across A-A', B-B` and C-C’ profiles in the studied area 
has a cumulative behavior. This means the high radioactivity, the high total zircon and monazite.

\section{Profile B-B'}

eU and eTh curves are typical from north to middle of the this profile, while their relation becomes reversible in the rest of the profile.

The monazite curve is following the eTh curve only in the northern portion of this profile, this means that it is may be the only Thbearing mineral in that portion.

\section{Profile $\boldsymbol{C}$ - $\boldsymbol{C}^{\text {' }}$}

There is symmetrical behavior between eTh and monazite in this profile except in some portions at samples Nos. (43, 49 and 57 to 60). The reverse behavour between the variables may mean that the monazite is not the only Th-bearing mineral in those portions.

Zircon and eU curves are symmetrical in most of this profile except at samples Nos. (41 to 43 and 55 to 57 ). This can be attributed to the presence of U-bearing zircon along most of this profile with exception of the mentioned portions.

Monazite distribution curve is differing from that of eTh in most of this profile which may be attributed to the presence of other Thbearing minerals.

\section{CONCLUSIONS}

Mineralogical investigations showed that the radioactivity of the studied area is attributed to the occurrences of high relative concentrations of radioactive U- and/or Th-bearing minerals such as monazite and zircon.

Examination of the spectrometric measurements in the study area revealed that the concentrations of the three natural radioelements $\mathrm{K}$, eU and eTh range from 0.0 to $2.3 \%$ ppm, 0.0 to $3.6 \mathrm{ppm}$ and 0.7 to $17.7 \mathrm{ppm}$ respectively. The average (mean background) values of these radio-elements were comput- ed as $1.034 \%$ for $K, 1.34$ ppm for $U$ and 7.5 ppm for Th.

Both laboratory radiometric analyses and ground radio-spectrometric maps indicate that the studied area is characterized by low radioelement content in general. Meanwhile, they show a relatively high radioactivity zone in the northwestern part of the area, in addition to some of small zones in the north and west and another zone of relatively high thorium content at the center of the area.

The computed average exposure rate value $(4.682 \mu \mathrm{R} / \mathrm{h})$ represents the average environmental terrestrial radioactivity level in the study area. This value can be used as a reference to detect and determine the amount and extent of any possible future environmental variation in the natural terrestrial radioactivity level in this area that might result from natural or artificial sources. These sources usually affect both the terrestrial and atmospheric environs. Accordingly, a periodical systematic surveying is recommended for monitoring any changes in environmental radioactivity level that might occur in the area.

Different parts of the suggested sites range from less than $0.5 \mathrm{mS} / \mathrm{y}$ to about $1 \mathrm{mS} / \mathrm{y}$ averaging about $0.7 \mathrm{mS} / \mathrm{y}$. Therefore the radiation exposure dose rate in the different parts of the site is equal to or less than the permissible dose determined by the IAEA $(1 \mathrm{mS} / \mathrm{y})$. However, there are still some hazards arising from the radioactive minerals contained in the exposed beach sediments covering the site. The radiation is mainly attributed to the uranium and thorium phosphates contained in the monazite mineral, in addition to relatively weak radiation arising from some uranium atoms located in the crystal lattice of zircon.

In addition to the radiation exposure dose another type of radionuclide hazard occurs and may cause contamination to the environment that threatens the human safety. These hazards include the windblown sands, mixed with the radioactive minerals, and/or contamination that may occur to hands, nails 
and clothes of the laborers in the plant. The radio-nuclides in the radioactive minerals may reach their respiratory and/or digestive systems causing possible accumulation hazards to the people working in the plant site, especially during the site implementation and the construction period.

\section{RECOMMENDATIONS}

The interpretation of the obtained data reveals that the radiation exposure dose rates are almost equal to or less than the permissible dose suggested by the IAEA $(1 \mathrm{mS} / \mathrm{y})$. However there are possible hazards that may arise from possible inhalation dose caused by the radioactive minerals contained in the beach sand covering the site. The rate dose map indicate that the highest dose rate exists at the western zone of the site, whilst the lowest dose rate is attained at the eastern zone of the site.

It also reveals that the dose rates sharply decrease towards the southeastern zone. In addition, the exploration results obviously demonstrate that the mineral concentration in the beach sediments of the site is increasing due west of limited mineralization which occurs in this part. This part of resource in site area can be scarped to be utilized later in any future exploration plans conducted in the $\mathrm{Abu}$ Khashaba-Metoubas mineral zone.

The final recommendations suggested to achieve human safety and to make use of the mineral resources in the site can be presented in the following

1-Scraping of the upper $0.5 \mathrm{~m}$ of beach sediments, at the relatively higher heavy minerals content (the western part in the present study).

2-These scraps may be conducted using dozer operations. The scraped cover should be moved to NMA prototype unit in $\mathrm{Abu}$ Khashaba town to utilized later.

3-Both the scarped part and non-scarped part are then covered by the radiation free soil supported by mixing with a part of sealing materials, the implemented overburden is then compressed and covered to a thickness of 0.5-0.6 $\mathrm{m}$ above the present level.

To avoid the inhalation doses as well as the digestive hazards, the suggested solution is to undertake the following:

1- Fencing of the site should attain suitable elevation to reduce attack by windblown sand. It should be constructed inside the covered site by at least $10-20 \mathrm{~m}$ from all sides. In addition, planting trees around the fence will effectively reduce the effect of windblown sands mixed with radioactive minerals.

2- For laborers protection; heavy restriction must be made during installation of the overburden cover of the site. Hands, nails and full bodies wash should applied.

3- Construction of an asphalt road inside the site is quite necessary in order to avoid sand blowing during car passages.

4- The digging for foundation is preferable to be undertaken by machines as far as possible.

5- Laborers should be subjected to radiation safety examination, at least once a year.

Furthermore, the obtained data set could be used as background levels for future research applications and development of environmental regulatory frameworks along the northern coast.

\section{Acknowledgements}

The authors are grateful to Prof. Hamdy S. Sadek for his consultation during research work, Prof. Mohsen M. Ali, the President of the Nuclear Materials Authority and Professor Adel F. Khalil, the head of the exploration Division for the facilities they furnished to complete this work. Also, the authors acknowledge the effort for the junior geophysicists Islam M. Hussain, Hussain F. Abd Elsalam and Hitham F. Ahmed for their help during field measurements. 


\section{REFERENCES}

Abdelhady, H.H.; El Sadek, M.M.; Gharieb, A.G.; Zaieimah, M.A.M., and Gaafer, I.M.E., 2004. Analysis and interpretation of the ground spectrometric and magnetic survey of the black sand beach deposits of Abu Khashaba/ Al- Burullus estuary, east Rosetta area, Mediterranean Coast, Egypt. (Final Stage). Internal Report, NMA, Cairo, Egypt, 89 p.

Abdel Razek, Y.A.; Bakhit, A.F., and El Hadary, A.F., 2009. Terrestrial radiation and estimation of its hazards at Baltim area. Sedimentology of Egypt, 17, 217-226.

Dabbour, G.A., 1980. Geological and mineralogical studies on rutile in black sands deposits from the Egyptian Mediterranean coast. Unpub. Ph.D. Thesis, Fac. Sci., Cairo Univ., $154 \mathrm{p}$.

Dabbour, G.A.; Morsy, M.A., and Kamel, A.F., 1988. Radioactivity and heavy economic minerals of some Quaternary sediment at Al Arish beach, North Sinai, Egypt. Ann. Geol, Surv. Egypt, 16, 51-56.

EBASCO Services Incorporated, Geelip Team, 1964. Evaluation of proposed program for development of mineral deposits of Egyptian Black Sand's Company. Cairo, Five year Planning Organization.

Elder, J., and Domenico, J., 2000. Enhancing mineral quality through magnetic separation. Indust. Miner., 27-33.

El Fishawi, N.M., 1985. Textural characteristics of the Nile Delta coastal sands. An application in reconstructing the depositional environments.
Acta Miner. Petr. Szeged, 27, 71-88.

El Fishawi, N.M., and El Askary, N.A., 1981. Characteristic features of coastal sand dunes along Burullus-Gamasa stretch, Egypt. Act Miner. Petr., Szeged, 25, 63-76.

Frihy, O.E., 1988. Nile Delta shoreline changes: aerial photographic study of a 28 year period. J. Coast. Research., 4/4, 597-606.

El Shazly, E.M., and Wassef, S.N., 1984. Ground radiometric surveying as a tool for heavy minerals content exploration in Mediterranean beach sands of Nile derivation. Egypt J. Geol., 28, No. 2, $283-289$.

Hammoud, N.M., 1966. Concentration of monazite from Egyptian black sands, employing industrial techniques. Unpub. M. Sc. Thesis, Fac. Sci., Cairo Univ., 201 p.

International Atomic Energy Agency (IAEA), 2010. Tech Report No. 419, 84p.

International Atomic Energy Agency (IAEA), 1991. Airborne gamma-ray spectrometer survey. Technical reports series. No. 323, 97p.

El Sirafy, M.A.; Aref, A.A., and Ismail, A.A., 2002. High resolution airborne geophysical survey flown over the black sand beach deposits, Northern coast of Delta, Egypt. Sci. Rep. Seri., AGD-Ed, 4/99.

Nuclear Materials Authority (NMA), 2004. Evaluation of the mineral sand reserve in $\mathrm{El} \mathrm{Bu}$ rullus dune belt. NMA Project 2037/5, NMA, Cairo, Egypt.

Tourre, J.M., 1999. Rare earths: Recent market trends. Indus. Miner., Jan., 37-43.

\section{دراسة مخاطر الاشعاعات الطبيعية في منطقة مطوبس، شمال دلتا التيل، مصر:

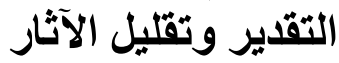


عمر انية بتلك المناطق مع عدم إهدار القيمة الاقتصادية لتواجد خام الرمال السوداء وتخفيف ومعالجة

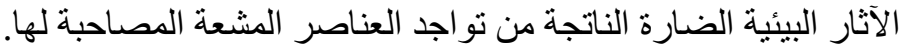

تهدف الدراسة إلى تقييم المستوى الإشعاعي وتحديد نسب تركيز المعادن الاقتصادية لمنطقة

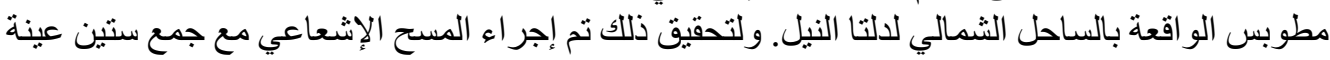

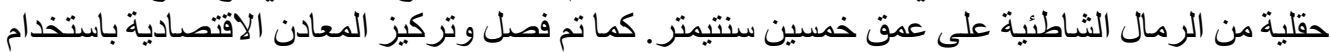

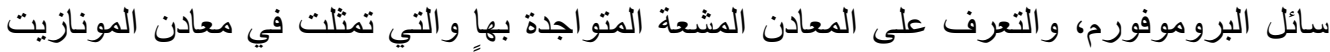

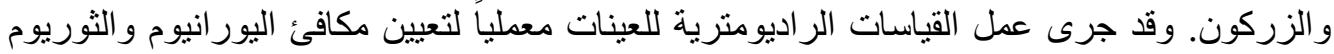

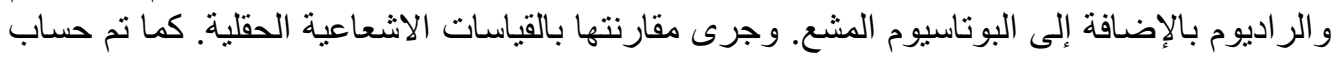

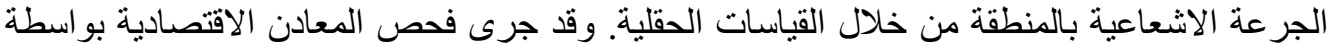

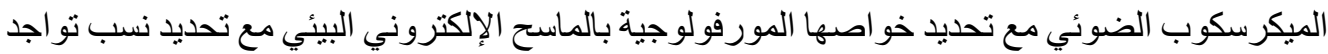
كل معدن على حدة في جميع العينات.

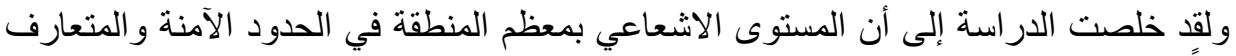

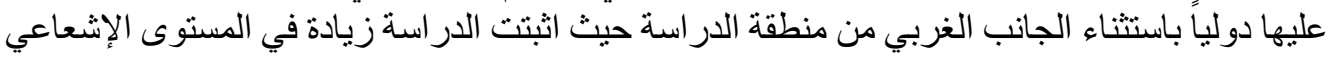
مصحوبة بزيادة في نركيز المعادن الاقتصادية.

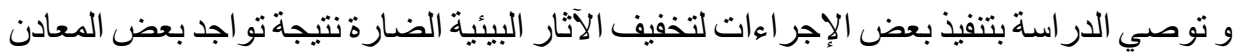

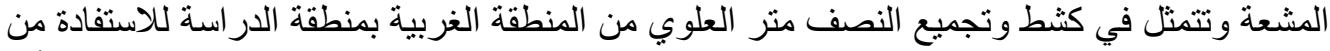

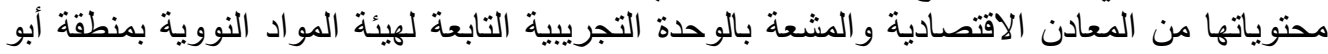

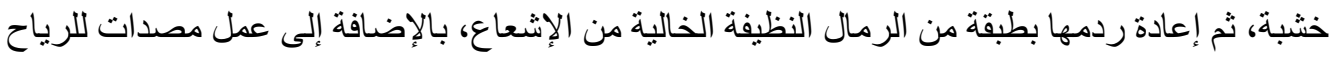

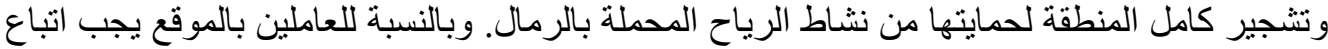

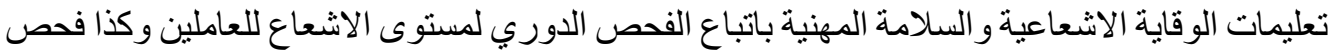
الاجهزة و المعدات المستخدمة بالموقع. و أخيراً يمكن استخدام البيانات المتحصل عليها بهذه الدراس استة كقاعدة بيانات يمكن الاستفادة منها

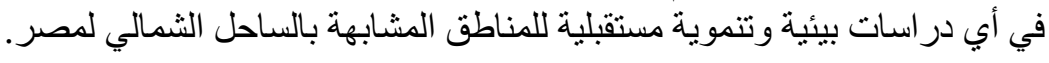

